\title{
Utilization of Palm Oil Mill Effluent (POME) for Biogas Power Plant; Its Economic Value and Emission Reduction
}

\author{
Deffi Ayu Puspito Sari, Dessy Fadiilah, Aqil Azizi \\ Environmental Engineering Universitas Bakrie, Jakarta
}

\begin{abstract}
Palm oil processing in palm oil mill produce solid and liquid waste. The liquid waste comes from the sterilization and clarification process, that are often called as Palm Oil Mill Effluent (POME). POME produce methane gas emissions that prompt climate change. Even though it releases a methane gas and has high Chemical Oxygen Demand (COD) content, POME has the potential to be a source of energy for biogas power plants. Then it utilized to produce electricity and supply the needs in factories or surrounding areas. This utilization also resulted in reduction of greenhouse gas emissions (specifically those resulted from the release of methane by POME). The purpose of this study was to determine the amount of emissions produced from palm oil mills in the process of degradation of residual waste production. This study also aims to determine the economic value of electricity produced by the biogas power plant. Company`s calculation standard contrasted with IPCC calculation to gauge the amount of emissions produced from the degradation process of POME and Empty Fruit Bunch (EFB). The average emissions produced in the waste processing sector annually was $9,503 \mathrm{t}-\mathrm{CO}_{2} /$ year and the economic value of electricity generated was IDR 1,866,370/day.
\end{abstract}

Keywords: Palm Oil Mill, Climate Change, Emission Calculation, Greenhouse Gases Reduction, Renewable Energy.

\section{Introduction}

The waste from processing palm oil is divided into solid waste and liquid waste. The solid waste is in the form of empty bunches, fibers and shells, while the liquid waste comes from the sterilization and clarification process are often called as Palm Oil Mill Effluent (POME). Palm oil mill effluent (POME) and empty bunches (EFB) are produced in large amount as a by-product [1]. The processing of POME which is widely used today is an anaerobic pond system, which is not environmentally friendly. This is because a large amount of greenhouse gas produced is released to the atmosphere instead of captured [2]. The waste released by the palm oil mills, such as the empty bunches of waste and liquid waste have the potential to produce methane gas emissions that leads to global warming and climate change [3][4]. The impact of the climate change affects the livelihood of the farmers, forest fire disaster and drought [5][6] [7].

POME can release methane gas into the atmosphere due to the degradation of organic compounds. Methane is one of six greenhouse gases set by the Kyoto Protocol. Besides releasing methane gas, POME from palm oil waste has a very high content of COD (Chemical Oxygen Demand), around 60,000-90,000. Even though it releases a methane gas and has a high COD content, POME has the potential as an alternative energy for biogas power plants. Figure 1 shows the POME collected in cooling pond. The water used for extraction process discharged into sludge pit and cooling pond, which known as POME. Small amount of oil leaked from various stage into this pond. The oil is separated and accumulated. It creates a thick surface on top of the cooling pond. Oil that recovered from cooling pond is called sludge palm oil (SPO). [8][9]

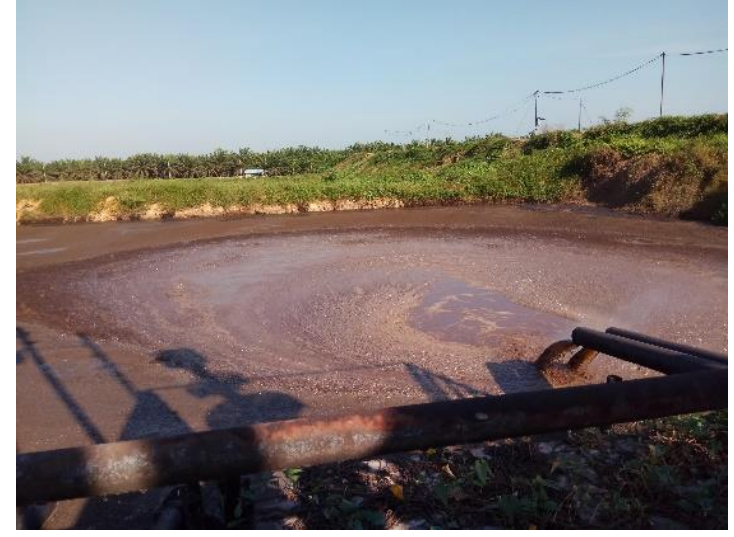

Figure 1. POME in the Cooling Pond 
Some studies revealed that utilization of palm oil as biofuels to replace fossil diesel can help reduce the greenhouse gas emissions in the GHG emissions life cycle [10]. The methane released from the remaining POME processing process has been used as biogas power plant to meet electricity needs in factories and worker housing. POME is degraded under anaerobic conditions to produce methane gas in bio-digestion tanks.

Carrying out the process of processing palm oil wastewater into a Biogas Power Plant, has resulted in reduction of greenhouse gas emissions (especially those resulting from the release of methane by POME). The purpose of this study were to determine the amount of emissions produced from palm oil mills in the process of degradation of residual waste production and economic value of electricity produced by the biogas power plant.

\section{Research Methodology}

The study was conducted in one of oil palm plantation and processing in East Belitung Regency, Bangka Belitung. The mill produces CPO (Crude Palm Oil) and Palm Kernel with raw materials of oil palm fruit or Palm Fruit Bunches (FFB) which have been operating since 2000.

Currently, the utilization of electricity generated from the biogas power plant was limited to the factory environment and had not been distributed to the community. Communities around the factory still used electricity supplied by state electrical company (PLN). POME was degraded under anaerobic conditions to produce methane gas in 3 bio digestion tanks with a total capacity of $16,000 \mathrm{~m}^{3}$ and a floating tank with a capacity of $3,200 \mathrm{~m}^{3}$.

The research framework was described in Figure 2. Based on the research framework, the initial stage of this research was looking for literature from various sources that are related to the research to be carried out. Secondary data collected were the number of empty bunches in the plant and those that have been composted, POME and the POME that converted in the bioreactor.

The data was collected from palm oil mill where the research conducted. The data were collected to calculate emission after installing biogas power plant including daily row material, daily liquid waste flow, COD loading, emission sources at the location and the calculation of GHGs generated. Emission data after installing biogas power plant compared with data on emission sources before biogas power plant installation. Both data then analyzed to know the amount of emission and economic value of electricity produced by biogas power plant.

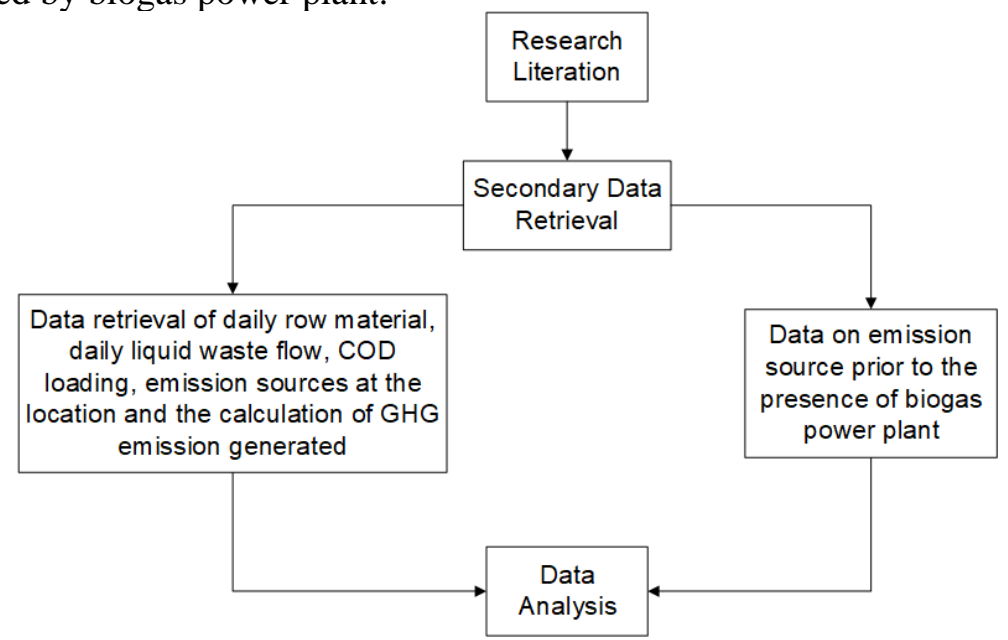

Figure 2. Research Framework

Emissions from EFB were also calculated in this study, both EFB returned to the plantation or EFB which had been processed as a composter. There was no emissions from stem waste, because the plantation was still the first planted and had not been replanted.

The description stated before was a description of the emission calculation formula based on IPCC 2004 [11]. 


\section{Emission total of $\mathrm{CH}_{4}$ from liquid waste \\ Emission $\mathrm{CH} 4=\sum_{i}[(T O W i-S i) \mathrm{EFj}-\mathrm{Ri}$}

In contrast, the calculations conducted at the palm oil mill, then linked to the 2006 IPCC Chapter 5 volume 6 of Wastewater Treatment and Discharge. Emission calculation formula carried out by the mill is as follow:

$$
\begin{aligned}
& \begin{array}{l}
\text { Emission }= \\
(\text { Total EFB })))
\end{array}(\text { Total POME } x \text { POME emission factor }) x(1-((\text { EFBgarden }+ \text { EFB compos }) / \\
&+\left(\frac{\text { EFB garden }}{\text { Total EFB }}\right) \times(\text { total Pome } x \text { Emission EFBgarden and cooling pond }) \\
&+\left(\frac{\text { EFB compos }}{\text { Total EFB }}\right) \times(\text { total Pome } x \text { Emisi EFB compos and POME }) \\
& x\left(1-\left(\frac{\text { POME reactor }}{\text { Total POME }}\right)\right) \times \text { allocationfactor }
\end{aligned}
$$

According to Schmidt [12] that the main sources of POME are; condensate of sterilizers (36\% of POME), clarification wastewater (60\% of POME) and hydro cyclone wastewater from the separation of shells and fibers (4\% of POME). Decomposition of organic matter in POME causes methane emissions of $13 \mathrm{~kg} \mathrm{CH}_{4}$ per $\mathrm{t}$ POME (methane gas from $65 \%$ biogas, methane emissions $18.2 \mathrm{~m} 3$ per $\mathrm{t}$ POME, methane density $0.717 \mathrm{~g} / \mathrm{liter}$ ). Schmidt has used the calculation of $8.743 \mathrm{~kg} \mathrm{CH} 4$ per t FFB (this is derived from the equation $672.5 \mathrm{~kg}$ POME/1000 $\mathrm{kg}$ FFB x $13 \mathrm{~kg} \mathrm{CH}_{4}$ ). The GHG factor (in $\mathrm{RED})$ for $\mathrm{CH}_{4}$ is 23 .

According to calculation data the mill, the POME from the factory shows that $\mathrm{CH}_{4}$ emissions per 1 metric tons (MT) of POME is $12.12 \mathrm{~kg} \mathrm{CH}_{4}$ at a temperature of $301.15 \mathrm{~K}$. This data is obtained from the calculation as follows:

$\operatorname{Gas} \operatorname{Law}(\mathrm{n})=\frac{P V}{R T}$

$$
=\frac{1 \times 18720}{0.08206 \times 301.15}=757.5 \mathrm{mols}
$$

Methane gas emission at $65 \%$ in $\mathrm{m}^{3}=18.72$, in terms of liter $=18720$.

$\mathrm{R}=\mathrm{a}$ constant $=0.08206 \mathrm{~L}$ atmos $/ \mathrm{mol} / \mathrm{K}$

$\mathrm{T}=$ temperature at $28^{\circ} \mathrm{C}=301.15^{\circ} \mathrm{K}$

Weight of methane gas in $18.72 \mathrm{~m}^{3}$

$$
=757.5 \times 16=12120.246 \mathrm{gr}=12.12 \mathrm{~kg}
$$

For EFB emission factors in the garden and cooling pond, as well as EFB emission factors for compost derived from ISCC 205 GHG Emissions Calculation Methodology and GHG Audit ISCC 1103-15 [12]. Based on these sources, the required emission factor is attached in table 1.

Table 1. Emission Factor

\begin{tabular}{ccc}
\hline $\begin{array}{c}\text { POME } \\
\text { emission factor }\end{array}$ & EFB land emission factor & $\begin{array}{c}\text { Composting EFB emission } \\
\text { factors }\end{array}$ \\
\hline 278.76 & 180 & 10 \\
\hline
\end{tabular}

Palm Kernel Oil extraction is outside the system boundary of this calculation, so that a portion of the emissions and releases of oil palm cultivation and the production of crude palm oil must be allocated to the palm kernel that leaves the system. Allocation with mass or energy is recommended by 
the ISO 14040 standard. The mass allocation results are converted to energy allocation using LVH (Left ventricular hypertrophy) for CPO (39.3 MJ / kg) and PK (21.1 MJ / kg).

Allocation Factor

$=\frac{\mathrm{CPO} \times 1000 \times 39.3}{\mathrm{CPO} \times 1000 \times 39.3+\text { kernel } 1000 \times 21.1}$

The method of calculating the economic value of electricity use per KWH that can be reduced by the presence of a biogas power plant follows the POME to Biogas Conversion Project Development Guide in Indonesia, USAID From American People \& Winrock International. The calculation is done to determine the generation capacity per $\mathrm{KWH}$, then compared with the electricity price per KWH charged when using electricity from PLN.

Calculation of Electric Power Potential:

1. Daily raw material (tons of FFB / day) $=\frac{\text { TBS Olahan Tahunan }}{\text { Hasil operasi dalam setahun }}$

2. Daily liquid waste flow ( $\mathrm{m} 3$ / day)

$=$ volume limbah cair harian $x$ rasio POME terhadap TBS

3. COD loading (kg COD/day)

$=$ COD $x$ aliran limbah cair harian $x \frac{\mathrm{kg}}{1000000 \mathrm{mg}} \times \frac{1000 \mathrm{l}}{\mathrm{m} 3}$

4. $\mathrm{CH}_{4}$ Production $\left(\mathrm{NM}^{3} \mathrm{CH}_{4} /\right.$ hari)

$=$ COD loading $x$ COD eff $x$ CH4/COD

5. Generation Capacity (MWe)

$=\frac{\text { Produksi CH4 } \times \text { CH4,ev } \times \text { Gen eff }}{24 \times 60 \times 60}$

Source : [13]

\section{Result and Discussion of the Data}

Data from oil palm fruit bunches produced from 3 nucleus estates and 5 outer gardens are obtained annually from one of palm oil mill in Belitung Island. In Table 2, there are data on FFB per year calculated from October and ending in September.

Table 2. Total FFB data per year

\begin{tabular}{cr}
\hline Year & $\begin{array}{c}\text { Total product (ton } \\
\text { FFB / year) }\end{array}$ \\
\hline oct 10 - sep 11 & 277881.04 \\
oct 11 - sep 12 & 341870.8 \\
oct 12 - sep 13 & 426975.42 \\
oct 13 - sep 14 & 440356.10 \\
oct 14 - sep 15 & 439372.94 \\
oct 15 - sep 16 & 371191.42 \\
oct 16 - sep 17 & 372864.51 \\
\hline
\end{tabular}

Source: Mill data

The annual empty bunch data was obtained from October and ending in September can be seen in Table 3. The empty bunches are then dumped into the land as fertilizer and some are used for composting.

Table 3. Empty Fruit Bunches Data

\begin{tabular}{crrr}
\hline Year & EFB & EFB in the Land & EFB for compost \\
\hline Oct 12-Sep 13 & 56544 & 56262 & 282 \\
Oct 13- Sep 14 & 91213 & 90717 & 496 \\
Oct 14 - Sep 15 & 91643 & 91643 & 0 \\
Oct 15 - Sep 16 & 77546. & 77546 & 0 \\
\hline
\end{tabular}

Source: Mill data 
In addition to the empty bunch data, the data on total POME generated and the POME entering the biogas bioreactor are also needed to calculate greenhouse gas emissions in the waste treatment sector. The total POME and POME data entered into the bioreactor can be seen in table 4 .

Table 4. POME Data

Source: Mill Data

\begin{tabular}{crr}
\hline Year & POME Total & POME to biogas \\
\hline Oct 12 - Sep 13 & 187,262 & 40,040 \\
Oct 13 - Sep 14 & 265,400 & 259,572 \\
Oct 14 - Sep 15 & 286,368 & 207,306 \\
Oct 15 - Sep 16 & 173,406 & 166,519 \\
\hline
\end{tabular}

In table 5, there are the emission calculations using equation 1 . The calculation uses the empty fruit bunch data in table 3 and the POME data in table 4 which is then multiplied by the emission factor attached to table 1 . The calculation of greenhouse gas emissions is carried out based on equation 1, then multiplied by the allocation factor calculated based on equation 5. The results of the emission calculation are attached in table 5.

Table 5. Waste Management Emission Calculation Results

\begin{tabular}{lr}
\hline \multicolumn{1}{c}{ Year } & \multicolumn{1}{c}{$\begin{array}{c}\text { Emission Kg } \\
\text { CO2eq }\end{array}$} \\
\hline Oct 12 - Sep 13 & $23,437,031.72$ \\
Oct 13 - Sep 14 & $929,613.84$ \\
Oct 14 - Sep 15 & $12,556,852.99$ \\
Oct 15 - Sep 16 & $1,089,058.36$ \\
Average & $9,503,139.23$ \\
\hline
\end{tabular}

Source: Mill data

The processing of methane gas from the resulting liquid waste can reduce the electricity usage costs. Table 6 shows the amount of electrical power that can be produced by the mill. The electricity used annually is calculated starting in October and ending in September.

Table 6. The Calculation of Average Power Generation Capacity Per Day

\begin{tabular}{lrr}
\hline & Oct 15 - sep 16 & Oct 16 - sep 17 \\
\hline Daily Liquid Waste Flow (m ${ }^{3} /$ day) & 493 & 671 \\
COD loading (kg COD/day) & 33,759 & 45,904 \\
Production of CH4 (NM3 CH$/$ day) & 9,743 & 13,216 \\
Power generation capacity (MWe) & 1.61 & 2 \\
Power generation capacity (KWe) & 1610 & 2000 \\
\hline
\end{tabular}

Dated March 1, 2017, public electrical company (PLN) in Belitung raised the price of electricity to IDR $1034 / \mathrm{kWh}$. The mill has reduced the economic cost they spend by replacing electricity from PLN to electricity from biogas processing, so that the electricity cost they reduce can be calculated in table 7.

Table 7. The Reduced Electricity Cost

\begin{tabular}{cccr}
\hline Year & Electricity Used (KWh) & $\begin{array}{c}\text { Price of electricity / } \\
\text { KWh (IDR) }\end{array}$ & $\begin{array}{c}\text { Reduced Electricity Cost } \\
\text { / day (IDR) }\end{array}$ \\
\hline oct $15-$ & 1610 & $1,034.00$ & $1,664,740.00$ \\
\hline
\end{tabular}




\begin{tabular}{|c|c|c|c|}
\hline sep 16 & & & \\
\hline $\begin{array}{c}\text { oct } 16- \\
\text { sep } 17\end{array}$ & 2000 & $1,034.00$ & $2,068,000.00$ \\
\hline Average & & & $1,866,370.00$ \\
\hline
\end{tabular}

Based on the calculations, the economic cost which can be reduced with the existence of Biogas Power Plants in 2016-2017 reaches IDR 2,068,000.00/day.

\section{Conclusion}

The conclusions obtained from this study are as follows:

1. The average emissions produced by the mill in the waste processing sector per year is $9,503,139.23 \mathrm{~kg} \mathrm{CO} 2 /$ year or 9,500 t-CO2/year.

2. Power generation capacity reached $1610 \mathrm{KWe}$ in October 2015 - September 2016 and 2000 KWe in October 2016 - September 2017

3. The average reduction in the economic cost of electricity generated is IDR $1,866,370.00$ /day

\section{Acknowledgement}

This research is supported by the research grants from Ministry of Research, Technology and Higher Education of Republic Indonesia, on scheme PTUPT contract number 11/AKM/PNT/2019 and Universitas Bakrie contract number 154/SPK/LPP-UB/III-2019.

\section{References}

[1] S. Saelor and P. Kongjan, "Biogas Production from Anaerobic Co-digestion of Palm Oil Mill Effluent and Empty Fruit Bunches," Energy Procedia, vol. 138, pp. 717-722, Oct. 2017.

[2] Y. Y. Choong, K. W. Chou, and I. Norli, "Strategies for improving biogas production of palm oil mill effluent (POME) anaerobic digestion: A critical review," Renew. Sustain. Energy Rev., vol. 82, pp. 29933006, Feb. 2018.

[3] I. Febijanto, "PENGURANGAN GAS RUMAH KACA DARI LIMBAH CAIR DI PABRIK KELAPA SAWIT PT PERUSAHAAN NUSANTARA, RIAU,” JRL, vol. 5, no. 3, pp. 233-244, 2009.

[4] S. Yacob, M. A. Hassan, Y. Shirai, M. Wakisaka, and S. Subash, "Baseline study of methane emission from open digesting tanks of palm oil mill effluent treatment," Chemosphere, vol. 59, no. 11, pp. 15751581, Jun. 2005.

[5] A. Mursidi and A. D. P. Sari, "Management of drought disaster in Indonesia," J. Terap. Manaj. dan Bisnis, vol. 3, no. 2, pp. 165-171, 2017.

[6] D. A. P. Sari, F. Rumambi, and R. Nurmasari, "Social Economic Resilience in Facing Land and Forest Fire Disaster (Case Study in South Sumatra Province)," J. Terap. Manaj. Dan Bisnis, vol. 4, no. 1, p. 10, 2019.

[7] D. A. P. Sari, F. Falatehan, D. S. Irawan, G. Sedana, and R. Rahim, "Mitigation and Adaptation Analysis of the Climate Change Impact Using Sustainable Livelihood Model," Int. J. Eng. Technol., vol. 7, no. 2.5, pp. 108-114, 2018.

[8] M. A. A. Bakar, W. J. Yahya, and Z. Mohamad, "Akademia Baru Pollution Reduction Technology in Palm Oil Mill through Effluent Treatment and Management Akademia Baru," vol. 1, no. 1, pp. 8-15, 2016.

[9] W. Yoochatchaval, S. Kumakura, D. Tanikawa, T. Yamaguchi, M. F. M. Yunus, S. S. Chen, K. Kubota, H. Harada, and K. Syutsubo, "Anaerobic degradation of palm oil mill ef fl uent ( POME )," pp. 20012008, 2011.

[10] T. Silalertruksa, S. H. Gheewala, P. Pongpat, P. Kaenchan, N. Permpool, N. Lecksiwilai, and R. Mungkung, "Environmental sustainability of oil palm cultivation in different regions of Thailand: Greenhouse gases and water use impact," J. Clean. Prod., vol. 167, pp. 1009-1019, 2018.

[11] IPCC, "CHAPTER 6: Wastewater Treatment and Discharge," 2006.

[12] J. Schmidt, "Life cycle assessment of rapeseed oil and palm oil: Ph.D.thesis, Part 3: Life cycle inventory of rapeseed oil and palm oil, Jannick H Schmidt, Department of Development and Planning," 2017.

[13] "ISCC 205 GREENHOUSE GAS EMISSIONS Content," 2016.

[14] Winrock International, "Konversi POME Menjadi Biogas," 2015. 